\title{
Rational modes of wool scouring
}

\section{Tetiana Romanovska, Mykola Oseiko, Svitlana Bazhay-Zhezherun, Olena Yarmolitska}

\author{
National University of Food Technologies, Kyiv, Ukraine
}

\begin{tabular}{|c|c|}
\hline & Abstract \\
\hline Keywords: & Introduction. Currently, synthetic detergents with a \\
\hline \multirow{5}{*}{$\begin{array}{l}\text { Wool } \\
\text { Grease } \\
\text { Scouring } \\
\text { Surfactant }\end{array}$} & weakly alkaline $\mathrm{pH}$ are used for scouring wool. The \\
\hline & combination of surfactant Sles 70 with an aprotic organic \\
\hline & solvent with dimethylsulfoxide (DMSO) allows you to create \\
\hline & a neutral detergent and needs to determine the rational modes \\
\hline & $\begin{array}{l}\text { of wool scouring. The purpose of our study was to find the } \\
\text { rational parameters of scouring fine-wool hair. }\end{array}$ \\
\hline Article history: & $\begin{array}{l}\text { Materials and methods. In Latin squares, an } \\
\text { experiment was conducted to determine the effect of the } \\
\text { concentration of Sles } 70 \text { in the scouring solution in the range }\end{array}$ \\
\hline \multirow{4}{*}{$\begin{array}{l}\text { Received } \\
14.09 .2019 \\
\text { Received in revised } \\
\text { form } 09.11 .2019 \\
\text { Accepted } \\
28.11 .2019\end{array}$} & of 0.1 to $3.1 \mathrm{~g} / \mathrm{dm}^{3}$, the concentration of DMSO 0.01 to 0.61 \\
\hline & $\mathrm{g} / \mathrm{dm}^{3}$, the hydromodule 10 to 100 , the temperature of \\
\hline & $\begin{array}{l}30-48^{\circ} \mathrm{C} \text { for cleaning fine-wool fibers while scouring the } \\
\text { wool fiber with the specified combined detergent. }\end{array}$ \\
\hline & Results and discussion. In the investigated range of \\
\hline & $\begin{array}{l}\text { variation of factors, the influence of the hydromodule on the } \\
\text { purification of wool and the extraction of extractive } \\
\text { substances from the surface of the fiber into the waste }\end{array}$ \\
\hline $\begin{array}{l}\text { Corresponding } \\
\text { author: }\end{array}$ & $\begin{array}{l}\text { solution was most pronounced. } \\
\text { Hydro module } 40 \text { and more allows you to clean the wool } \\
\text { from grease and dirt. The temperature has a stable effect in } \\
\text { the given range, so all the investigated values of temperature }\end{array}$ \\
\hline \multirow{3}{*}{$\begin{array}{l}\text { Tetiana } \\
\text { Romanovska } \\
\text { E-mail: } \\
\text { rombiotann@ukr.net }\end{array}$} & contribute to the removal of fatty contaminations of wool for \\
\hline & this component of the detergent solution. \\
\hline & $\begin{array}{l}\text { According to the hydromodule } 70 \text { and } 100 \text {, as well as the } \\
\text { concentration of } 1 \% \text { by weight Sles } 70-\text { that is, for } \\
\text { concentrations of surfactants above the critical concentration } \\
\text { of micelles }(\mathrm{CCM}) \text { - the fibers of wool are also cleared }\end{array}$ \\
\hline & $\begin{array}{l}\text { during scouring. It is logical to note that the concentrations } \\
\text { of surfactants below the CCM have reduced the effectiveness } \\
\text { of wool cleaning. The concentration of DMSO also had a } \\
\text { slight effect on the wool treatment compared to the } \\
\text { hydromodule. }\end{array}$ \\
\hline & $\begin{array}{l}\text { Conclusions. The rational mode of single scouring of } \\
\text { wool is the use of a hydromodule } 40 \text {, a concentration of } 1 \% \\
\text { by weight. Sles } 70 \text { and DMSO concentration to } 0.61 \mathrm{~g} / \mathrm{dm}^{3} \\
\text { in the temperature range } 30-48{ }^{\circ} \mathrm{C} \text {. The quality of the }\end{array}$ \\
\hline DOI: & scouring can be improved by increasing the disposable water \\
\hline $\begin{array}{l}10.24263 / 2310- \\
1008-2019-7-2-13\end{array}$ & dispenser or by scouring it with a minimum of water. \\
\hline
\end{tabular}




\section{Introduction}

Pre-treatment of wool involves cooking, scouring, and drying. Typing (shaking) wool is used to remove easily separated contaminants (straw, sand). However, the presence of fat $[1,2]$, which lubricates the hair fiber and protects the flea from rain and dust contamination, does not contribute to the removal of all mineral contaminants. Therefore, in the future, the wool is cleaned of dirt during scouring. The process of scouring involves treating wool with detergent solutions to remove organic and mineral contaminants [3].

During scouring the wool on the process of scouring the dirt is influenced by the following factors: nature of contaminants and fibers, detergent, the hardness of water, the presence of electrolytes, $\mathrm{pH}$ of the scouring solution, temperature, mechanical influence on the surface of the fiber [4-6].

Wool is a natural fiber of protein nature [7]. It is known that the wool thin fibrous fiber has two layers: a scaly upper layer, created by horny cells, and a scalp-like inner layer made up by spindle-shaped cells. The fiber of the wool is called keratin. Molecular weight of keratin 60,000-1,000,000 a.o. The most effective sorption ability of moisture among all known fibrous materials is wool. The wool fiber is pierced with microscopic pores, which in dry condition have a size of $0.3-0.6 \mathrm{~nm}$, and after swelling in water $4-6 \mathrm{~nm}$. In the swollen state, fibers of wool in diameter increase by 10 times than the length [8].

There are two main modifications of the wool protein: $\alpha$ - (native fibers of wool) and $\beta$ structure (wool fibers, steam-treated or hot water) [9]. For light industry, it is important to have a conformation of the permanently fixed structure of keratin, which is obtained by treating the stretched fiber with steam.

One of the main characteristics of the protein is its isoelectric point. Keratin wool for the fiber of different breeds of sheep has an isoelectric point in the acidic region of $\mathrm{pH}$ values 4.2-4.8 [8]. In acidic medium, the fiber of the wool is more stable to hydrolysis, although the high temperature and high concentration of acid in the solution cause the hydrolysis of peptide bonds, which leads to the destruction of the fiber. The wool is easier to hydrolyze in the alkaline medium than in acidic. The wool in $3 \%$ hot solution of alkali is immediately hydrolyzed and dissolved. Soda and ammonia solutions destroy the fiber of wool less than alkalis. Disulphide and peptide bonds are degraded by the action of reducing agents and oxidants. During the action on hydrogen peroxide, disulfide bonds split off with sulfur deposition. At concentrations of up to $5 \mathrm{~g} / \mathrm{dm}^{3}$ of hydrogen peroxide and temperatures up to $60{ }^{\circ} \mathrm{C}$, pigments are bleached and keratin is practically not damaged. Loss of moisture in wool leads to its ability to electrify. At a temperature of $110-115^{\circ} \mathrm{C}$ the wool becomes fragile and markedly yellow. At temperatures above $150{ }^{\circ} \mathrm{C}$ begin the processes of thermal decay, which proceed more intensively at temperatures above $170{ }^{\circ} \mathrm{C}$ with the appearance of smell burned feathers [8].

The elemental layer of wool has the form (-NH-CO-CHR- $)_{n}$, and the surface is uneven and slippery. It is also known that fibers of wool have reactive groups. Therefore, especially wool and woolen fabrics are the most contaminated, compared with other natural fibers. The wool has hygroscopic properties and can hold up to $42 \%$ water [10]. At a temperature of 20 ${ }^{\circ} \mathrm{C}$ and relative humidity of $65 \%$, the humidity of the wool fiber is within $15-17 \%$ [8]. The electrokinetic potential of wool is $48 \mathrm{mV}$ [10].

During the scouring of wool, along with the separation of fiber dirt, a reversible sorption process occurs, and the cationic surfactants are most actively sorted on the wool fiber [10].

For wool, the temperature above $60{ }^{\circ} \mathrm{C}$ lowers elasticity of fibers. Also, the high temperature raises soap hydrolysis [11]. 
For treatment and scouring of wool fibers, surfactants are used [12-15]. Sodium, potassium, and ammonia soaps are anionic surfactants that have sufficient scouring and emulsifying properties but are sensitive to the action of acids and salts of water hardness. Also, anion-active surfactants are sulfonates - salts of sulfonic acids $\mathrm{RSO}_{3} \mathrm{Na}$, - which are different in structure and which include sulfonol. Sulphonols are sodium alkylbenzenesulfonates $\mathrm{C}_{n} \mathrm{H}_{2 n+1} \mathrm{C}_{6} \mathrm{H}_{4} \mathrm{SO}_{3} \mathrm{Na}(n=12 \div 18)$. Sulfonols are used as wetting agents and emulsifiers of dyes during dyeing of fabrics and as detergents that exhibit good scouring ability [8].

Anionic detergent is sodium laureth sulfate (Sles 70), solutions up to $3 \%$ of which have a $\mathrm{pH}$ of 6.5-9.5. Sles 70 is the main ingredient in the hair shampoo formula.

Non-ionic surfactants do not dissociate in aqueous solutions. Products of condensation of higher alcohols with ethylene oxide are nonionic surfactants and include sintanols. Synthanol DS-10 is a mixture of products with the general formula $\mathrm{C}_{n} \mathrm{H}_{2 n+1} \mathrm{O}\left(\mathrm{C}_{2} \mathrm{H}_{4} \mathrm{O}\right)_{m} \mathrm{H}$ $(n=10 \div 18, m=8 \div 10)$. Sintanol DS-10 is used in bleaching, dyeing of fibers and fur. Also, sintanol DS-10 has good emulsifying, dispersing and scouring properties.

Dimethylsulfoxide $\mathrm{C}_{2} \mathrm{H}_{6} \mathrm{OS}$ (DMSO) is an aprotic hygroscopic solvent, is soluble in water, ethanol, diethyl ether, chloroform, benzene. Looks like an oily liquid without odor. Thanks to the solvation of many organic and inorganic compounds widely used in cosmetics and medicines.

To remove fat from wool fiber use emulsion solvent, which to $90 \%$ contains an organic solvent (including gasoline), up to $50 \%$ aqueous sulfuric acid solution and an emulsifier (monoethanolamide) [UA $34016 \mathrm{~A}, 15.02 .2001$ ].

When scouring the wool fiber, a composition of synthesized surfactants, which includes anionic, nonionic surfactants and an organic solvent, is used. To remove contaminants and wool grease, a surfactant composition with a predominant anionic substance content (sodium dodecyl sulfate to $50 \%$ ) and nonionic substances (sintanol DS-10 and ricinose 80) and solvent (DMSO up to $10 \%$ ) are used [UA 32398 U, 12.05.2008]. Use composition of surfactants containing up to $55 \%$ nonionic surfactants (ricinox 80), as well as anionic (sulfonol) and least nonionic surfactant (sintanol DS-10) [UA 32960 U, 10.06.2008]. The effective effect is the composition "Sulpsid-MPSH", which includes up to $65 \%$ of nonionic surfactants (sintanol DS-10), as well as anionic (sulfonol) and up to $10 \%$ DMSO [UA 57000 U, 10.02.2011].

Therefore, nowadays for scouring wool synthetic detergents with low alkaline $\mathrm{pH}$ are used $[16,17]$. The search for effective detergents with neutral or slightly acid pH continues. The scientific and innovative combination surfactants based on Sles 70 with aprotic organic solvent DMSO will allow you to create a neutral detergent and will need to determine the rational modes of wool scouring.

The purpose of our study was to find the rational parameters of scouring fine-wool hair.

\section{Materials and methods}

\section{Materials}

The scouring of wool was studied with a combined detergent containing Sles 70 and DMSO. The selected kpmponents are chosen because the first one is a surfactant and the second one is the solvent of most organic substances. Solutions up to $3 \%$ Sles 70 have a pH of 6.5-9.5. The critical concentration of micelles (CCM) for Sles 70 at $20{ }^{\circ} \mathrm{C}$ is $0.55 \mathrm{~g} / \mathrm{dm}^{3}$ [18]. 


\section{Scouring solution preparation}

The scouring solution was prepared by dissolving an anionic detergent sodium laureth sulfate (Sles 70), replacing the classical alkaline solution with a solution with a neutral $\mathrm{pH}$ of the medium. The influence of the Sles 70 concentration in the scouring solution in the range of $0.1-3.1 \mathrm{~g} / \mathrm{dm}^{3}$, the concentration of DMSO $0.01-0.61 \mathrm{~g} / \mathrm{dm}^{3}$, the hydromodule $10-100$, and the temperature of $30-48{ }^{\circ} \mathrm{C}$ for removal from the sheep wool was determined extractives in a scouring solution.

\section{Experiment planning}

To find rational wool scouring options, the mathematical planning of the experiment in Latin squares was used. This experiment plan declares the absence of inter-factor effects. This involves the choice of independent factors and the use of the regression equations of the response dependence on the change of factors to find the optimal value of the factor in the selected range of variation. Each experiment experiment performed in triple repetition. Among the factors that were poured into the wool cleaning during scouring, the concentration of Sles 70 and DMSO in the scouring solution, the hydrodilution unit (water ratio: dry wool), the temperature was investigated.

The plan of the incomplete factor experiment is presented in the table 1 .

Table 1

Planning a partial quotient experiment by latin squares in physical quantities of factor levels

\begin{tabular}{|c|c|c|c|c|}
\hline $\begin{array}{c}\text { Experiment } \\
\text { No. }\end{array}$ & $\begin{array}{c}\text { Concentration } \\
\text { Sles 70, } \mathbf{g} / \mathbf{d m}^{\mathbf{3}}\end{array}$ & $\begin{array}{c}\text { Concentration } \\
\text { of DMCO, } \\
\mathbf{g} / \mathbf{d m}^{\mathbf{3}}\end{array}$ & $\begin{array}{c}\text { Hydraulic } \\
\text { module }\end{array}$ & $\begin{array}{c}\text { Temperature, } \\
{ }^{\mathbf{C}} \mathbf{C}\end{array}$ \\
\hline 1 & 0.1 & 0.61 & 40 & 42 \\
\hline 2 & 3.1 & 0.41 & 10 & 48 \\
\hline 3 & 2.1 & 0.01 & 70 & 36 \\
\hline 4 & 1.1 & 0.21 & 100 & 30 \\
\hline 5 & 3.1 & 0.61 & 100 & 36 \\
\hline 6 & 0.1 & 0.01 & 10 & 30 \\
\hline 7 & 1.1 & 0.41 & 70 & 42 \\
\hline 8 & 2.1 & 0.21 & 40 & 48 \\
\hline 9 & 2.1 & 0.41 & 40 & 30 \\
\hline 10 & 1.1 & 0.61 & 70 & 48 \\
\hline 11 & 0.1 & 0.21 & 10 & 36 \\
\hline 12 & 3.1 & 0.01 & 100 & 42 \\
\hline 13 & 1.1 & 0.01 & 10 & 42 \\
\hline 14 & 3.1 & 0.21 & 40 & 36 \\
\hline 15 & 2.1 & 0.61 & 100 & 48 \\
\hline 16 & 0.1 & 0.41 & 70 & 30 \\
\hline
\end{tabular}

In response to the change in factors, the refractive index of the waste water was used, the fat content in the misty wool, the surface tension of the detergent before scouring and in the spent scouring solution. 


\section{Results and discussion}

The influence of the investigated factors on the residual content of fat on the fiber of wool, on the refractive index of the waste of detergent solutions is given in Table 2.

Table 2

Influence the change of the factors of the incomplete factor experiment on fat content on the fiber (residual) and the refractive index of the spent scouring

\section{Solutions}

\begin{tabular}{|c|c|c|}
\hline $\begin{array}{c}\text { Experiment } \\
\text { No. }\end{array}$ & $\begin{array}{c}\text { Fat content on } \\
\text { fiber, \% wt }\end{array}$ & $\begin{array}{c}\text { Refractive index of waste } \\
\text { liquids, } \boldsymbol{n}\end{array}$ \\
\hline 1 & 12.74 & 1.3334 \\
\hline 2 & 10.31 & 1.3342 \\
\hline 3 & 11.14 & 1.3336 \\
\hline 4 & 10.23 & 1.3336 \\
\hline 5 & 10.81 & 1.3338 \\
\hline 6 & 16.02 & 1.3338 \\
\hline 7 & 10.99 & 1.3336 \\
\hline 8 & 11.73 & 1.3336 \\
\hline 9 & 10.88 & 1.3338 \\
\hline 10 & 10.26 & 1.3336 \\
\hline 11 & 10.12 & 1.3338 \\
\hline 12 & 11.19 & 1.3338 \\
\hline 13 & 11.42 & 1.3340 \\
\hline 14 & 10.95 & 1.3338 \\
\hline 15 & 11.29 & 1.3338 \\
\hline 16 & 11.14 & 1.3336 \\
\hline
\end{tabular}

In the investigated range of variation of factors, the most significant influence of the hydromodule on the purification of wool and on the transfer of extractives from the surface of the wool fiber to the treated scouring solution was most pronounced.

The plane describing the influence of the hydrodynamic modulus and the temperature in the normalized values on the refractive index of the used cleaning solutions has the form:

$$
n=0,0016 \cdot g^{2}-0,0098 \cdot g+0,00003 \cdot t+2,6815
$$

where $n-$ the refractive index of the used detergent solutions,

$g-$ scouring water module,

$t-$ scouring temperature.

On Figure 1 shows the plane of the refractive index of waste liquids, depending on the change in the parameters of the hydraulic module and the temperature in the normalized values. 


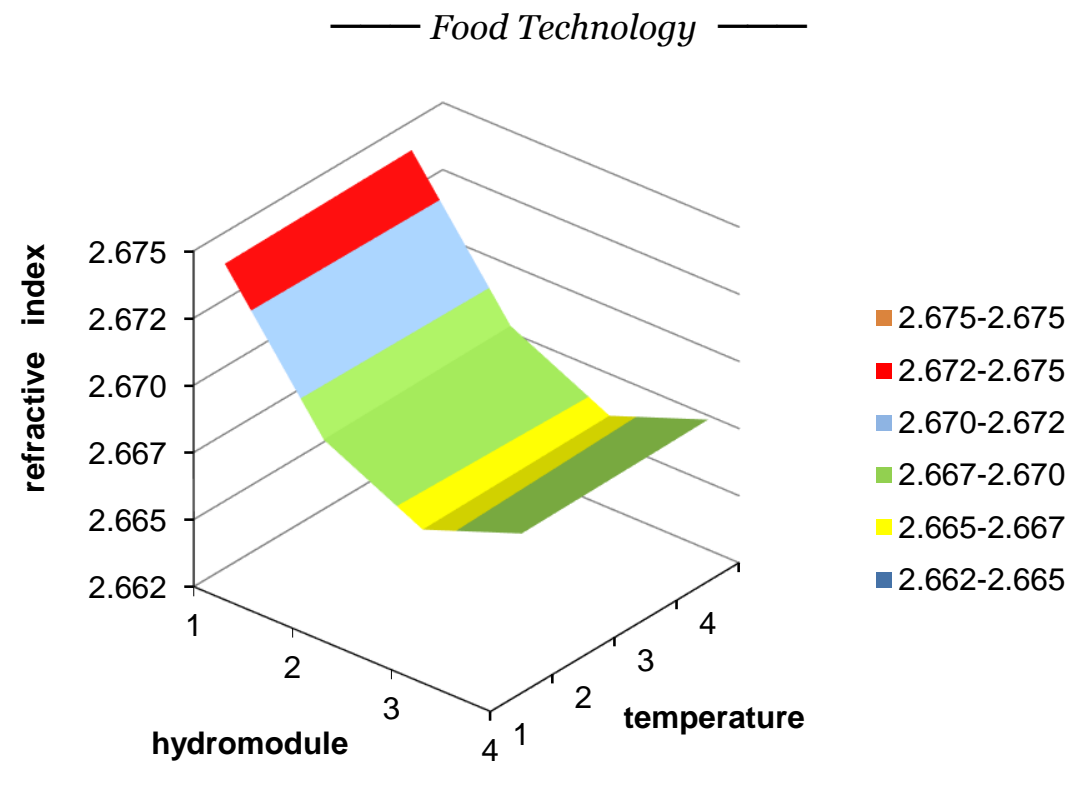

Figure 1. The response plane of the values of the refractive index of the spent scouring solution to the change of hydromodule and temperature taken in the normalized form

The smaller the hydromodule or the less the ratio of the scouring solution: dry wool, the more extractive substances pass into the waste solution.

The influence of temperature in the studied range is linear (see Figure 1). The content of the extracted substances dissolved in the spent scouring solution slightly increases with increasing temperature. This indicates that in the range of temperatures of $30-48{ }^{\circ} \mathrm{C}$ and for this component composition of the scouring solution all the pollutants of wool fibers are thoroughly dissolved in a scouring solution. Reducing the refractive index with the increase of the hydraulic module indicates dilution of contaminants in the scouring solution.

The plane describing the effect of the hydrodules and temperature in the normalized values on the residual fat content of the scoured wool fiber has the form:

$$
f=-0,3956 \cdot g-0,268 \cdot t+24,313
$$

where $f-$ the residual fat content of the scoured wool fiber,

$g-$ scouring water module,

$t-$ scouring temperature.

Determination of the fat content of the woolen fiber convinced that an increase in the hydrodules results in cleaner wool after scouring (Figure 2). 


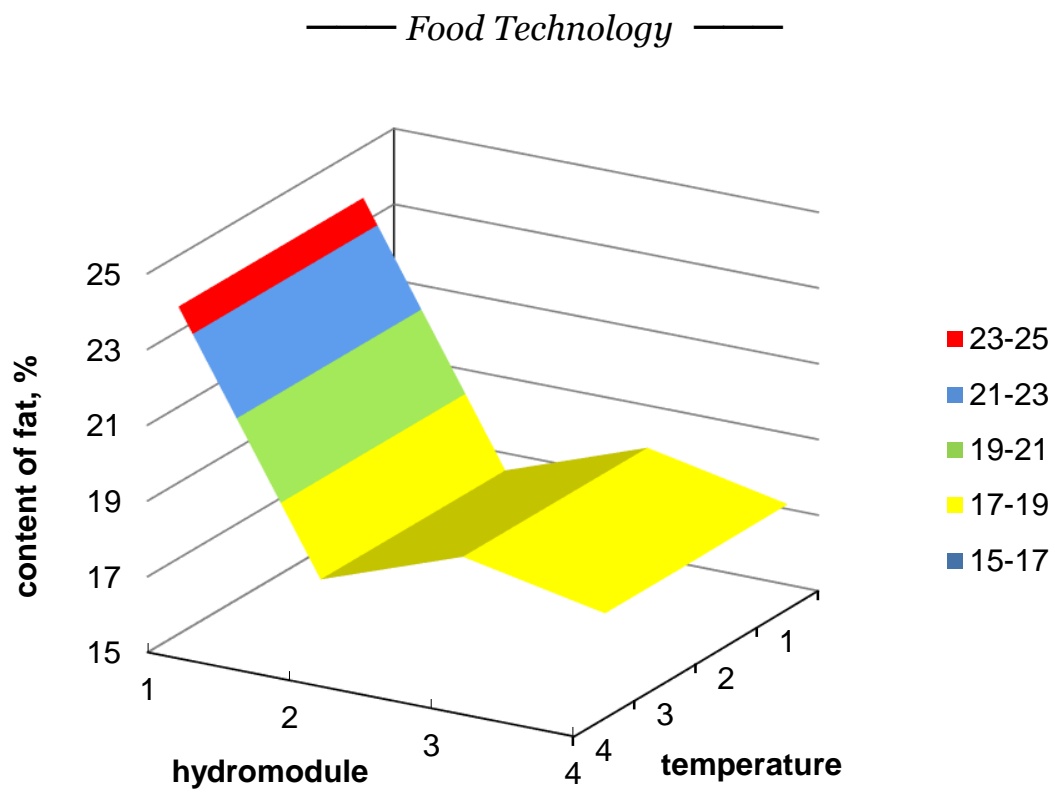

Figure 2. The response plane of the values of the residual fat content of the scoured wool fiber to the change of hydromodule and temperature taken in the normalized form

Hydromodule 40 and more allows you to clean the wool from grease and dirt. The temperature has a stable effect in the given range, so all the investigated values of temperature contribute to the removal of fatty contaminations of wool for this component of the detergent solution.

The plane describing the effect of the hydraulic module and the concentration of Sles 70 in the normalized values on the refractive index of the used cleaning solutions has the form:

$$
n=0,0016 \cdot g^{2}-0,0098 \cdot g+0,00004 \cdot c^{2}-0,0001 \cdot c+2,6815
$$

where $n-$ the refractive index of the used detergent solutions,

$g-$ scouring water module,

$c-$ concentration of Sles 70 in a scouring solution.

The plane describing the effect of the hydrodules and the concentration of Sles 70 in the normalized values on the residual fat content of the scoured wool fiber has the form:

$$
f=-0,3956 \cdot g+0,335 \cdot c^{2}-2,129 \cdot c+26,426,
$$

where $f-$ the residual fat content of the scoured wool fiber,

$g-$ scouring water module,

$c-$ concentration of Sles 70 in a scouring solution.

The concentration of Sles 70 in the scouring solution has even less effect on the scouring of contaminants in case of excess of its content in the solution of the amount of CCM (Figure 3 and Figure 4). 


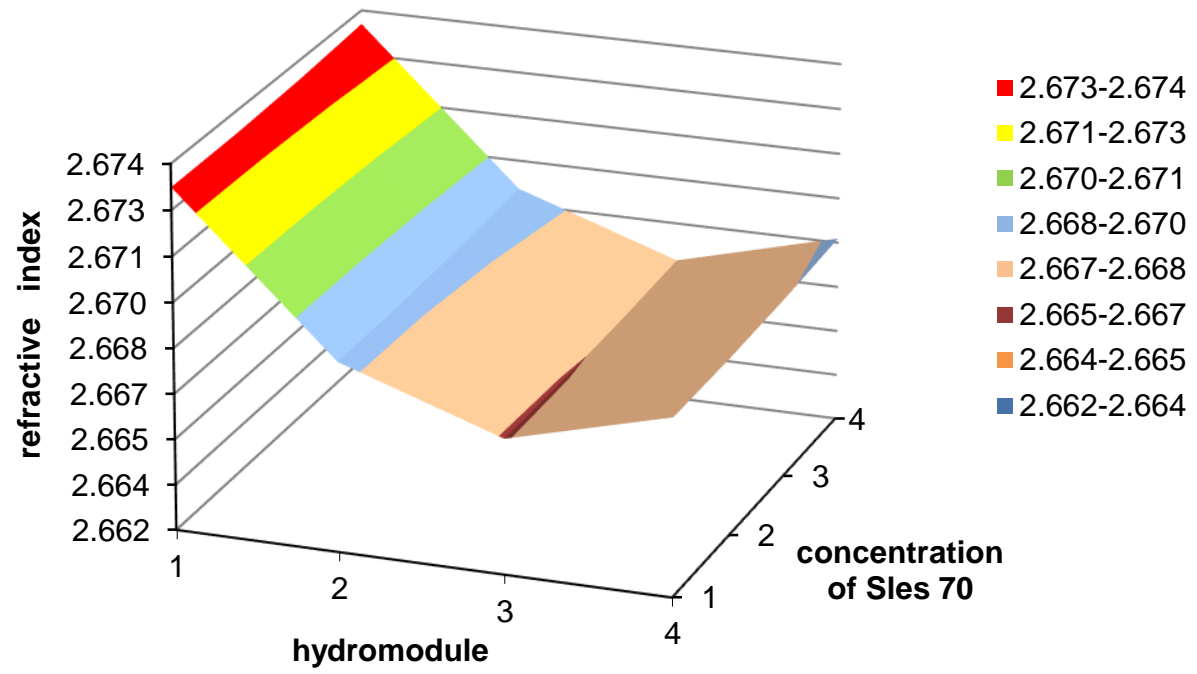

Figure 3. The response plane of the values of the refractive index of the spent scouring solution to the change of hydromodule and concentration of Sles 70 in a scouring solution taken in the normalized form

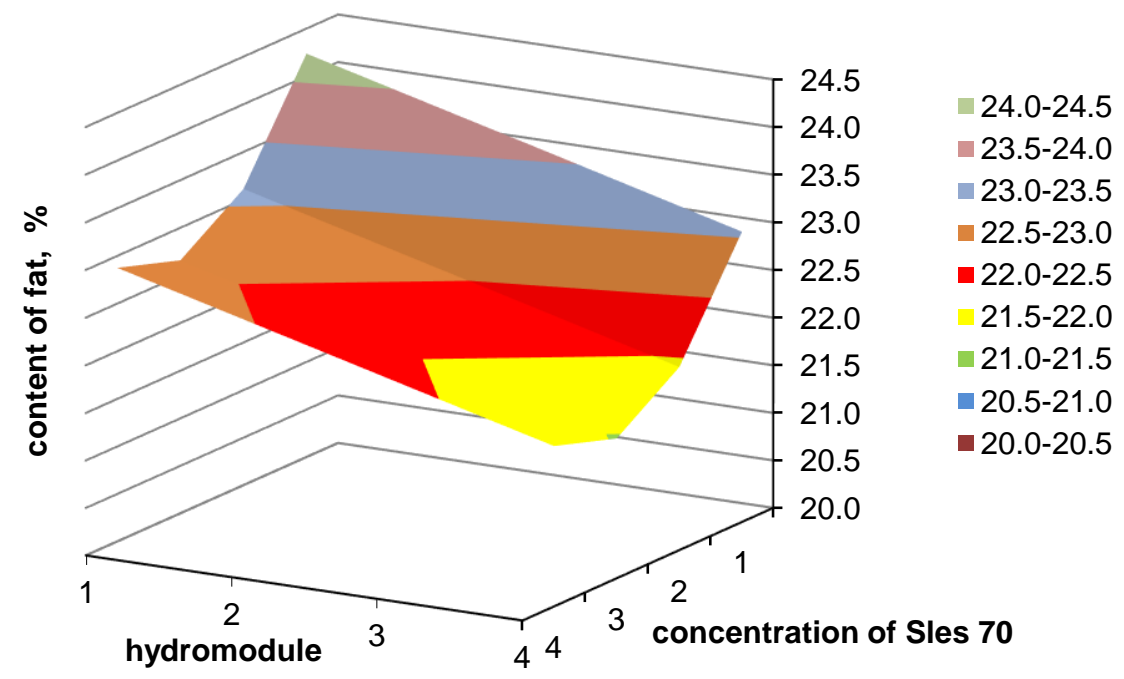

Figure 4. The response plane of the values of the residual fat content of the scoured wool fiber to the change of hydromodule and concentration of Sles 70 taken in the normalized form 
The significant influence of the hydromodule on the scouring process overshadowed the effects of other investigated factors. Consequently, it is possible either to increase the disposable hydraulic unit or to scour it repeatedly for a minimum hydromodule. For multiple scouring, it is important to completely change the scouring solution in the mode of periodic successive scouring [UA 55426 U, 10.12.2010; UA 114837 C2, 10.08.2017].

For the hydromodule 70 and 100, as well as the concentration of $1 \%$ by weight Sles 70 (ie, for concentrations of surfactants above CCM), the wool fibers are best purified during scouring. It is logical to note that the concentrations of surfactants below the CCM have reduced the effectiveness of wool cleaning. This is evidenced by the high content of residual fat in the misty wool (see Figure 4). The concentration of DMSO also had a slight effect on the wool treatment compared to the hydromodule.

\section{Conclusions}

Currently, synthetic detergents with a low-fat $\mathrm{pH}$ are used for scouring wool. The search for effective detergents with neutral or slightly acid $\mathrm{pH}$ continues. Combining Sles 70 with an organic DMSO solvent can create a neutral detergent and needs to determine the rational modes of wool scouring.

In Latin squares, an experiment was conducted to determine the effect of the concentration of Sles 70 in the scouring solution in the range of 0.1 to $3.1 \mathrm{~g} / \mathrm{dm}^{3}$, the concentration of DMSO 0.01 to $0.61 \mathrm{~g} / \mathrm{dm}^{3}$, the hydromodule 10 to 100 , the temperature of $30-48{ }^{\circ} \mathrm{C}$ for cleaning fine-wool fibers while scouring the wool fiber with the specified combined detergent.

In the investigated range of variation of factors, the most significant influence of the hydromodule on the purification of wool and on the transfer of extractives from the surface of the wool fiber to the treated scouring solution was most pronounced.

Hydromodule 40 and more allows you to clean the wool from grease and dirt. The temperature has a stable effect in the given range, so all the investigated values of temperature contribute to the removal of fatty contaminations of wool for this component of the detergent solution.

For the hydromodule 70 and 100, as well as the concentration of $1 \%$ by weight Sles 70 (ie, for concentrations of surfactants above CCM), the wool fibers are best purified during scouring. It is logical to note that the concentrations of surfactants below the CCM have reduced the effectiveness of wool cleaning. The concentration of DMSO also had a slight effect on the wool treatment compared to the hydromodule.

The rational mode of single scouring of wool is the use of a hydromodule 40 , a concentration of $1 \%$ by weight. Sles 70 and DMSO concentration to $0.61 \mathrm{~g} / \mathrm{dm}^{3}$ in the temperature range $30-48{ }^{\circ} \mathrm{C}$. The quality of the scouring can be improved by increasing the disposable water dispenser or by scouring it with a minimum of water.

\section{References}

1. Lopez-Mesas M., Carrillo F., Gutierrez M., Crespi M. (2007), Alternative metods for the wool wax extraction from wool scouring wastes, Grasas y aceites, 58(4), pp. 402-407.

2. Oseiko N.I. (2006), Tekhnolohiia roslynnykh olii, Varta, Kyiv. 
3. Oseiko N., Levchuk I., Romanovska T., Olishevsky V. (2015), Ecologic and economic efficiency comparison of lanolin extraction methods, Journal of EcoAgriTourism (Special issue), p. 167.

4. Romanovska T., Oseiko M. (2017), Aspects of wet wool cleaning, Ukrainian Journal of Food Science, 5(1), pp. 25-31, DOI: 10.24263/2310-1008-2017-5-1-5.

5. Oseiko N., Romanovska T. (2017), Resource saving wool scouring technology, Ukrainian Journal of Food Science, 5(2), pp. 207-216. DOI: 10.24263/2310-1008-20175-2-5.

6. López-Mesas M., Christoe J., Carrillo F., Gutierrez M.C., Crespi M. (2007). Supercritical fluid extraction as a clean-up method for the extraction of pesticides from wool wax. A preliminary approach, Grasas y aceites, 58 (2), pp. 148-153.

7. Sengupta A., Behera J. (2014), A comprehensive view on chemistry, manufacturing \& applications of lanolin extracted from wool pretreatment, American Journal of Engineering Research (AJER), 03(07), pp. 33-43.

8. Melnikov B.N., Vinogradova G.I. (1986), Primenenie krasiteley, Moscow.

9. Romanovska T.I. (2006), Fizyko-khimichni aspekty kharchovykh tekhnolohiy, Naukova dumka, Kyiv.

10. Nevolin F.V. (1971), Himiya i tehnologiya sinteticheskih moyuschih sredstv, Moscow.

11. Oseiko N., Romanovska T., Lyahovetskiy D. (2016), Study critical micelle concentration of scouring solutions, Food Science for Well-being: Book of Abstracts 8th Central European Congress on Food (CEFood 2016), Kyiv, p. 225.

12. Oseiko N., Romanovska T., Marinin A., Levchuk I. (2015), The properties of wool grease, Journal of EcoAgriTourism (Special issue), p. 168.

13. Caunce J.F., Barry S.I., Mercer G.N., Marchantb T.R. (2007), Numerical simulation of contaminant flow in a wool scour, Mathematical and Computer Modelling, 46, pp. 499 512, DOI: 10.1016/j.mcm.2006.11.032.

14. Jansen B.C., Hayes M. (1983), Retardation of wool growth in merino sheep caused by bacteria, Onderstepoort Journal of Veterinary Research, 50, pp. 271-274.

15. Michell G.H. (1991), Use of detergent in wool scouring, CSIRO Division of Textile Industry Symposium, pp. 41-55.

16. Oseiko N., Romanovska T., Tkachenko Y. (2016), Technological aspects for fat wool, Food Science for Well-being: Book of Abstracts 8th Central European Congress on Food (CEFood 2016), Kyiv, pp. 226.

17. Romanovska Tetiana, Oseiko Nick (2016), The features of the primary processing of wool, Proceedings of the International Conference: Modern technologies, in the food industry - 2016; international conference MTFI-2016, 20-22, Chişinău, pp. 266-267.

18. Oseiko N.I., Romanovska T.I., Lyahovetskiy D.O. (2016), Kharakterystyka myinykh rozchyniv pervynnoi obrobky vovny (Description of scouring solutions for primary wool processing), Scientific works of National University of Food Technologies, 22(5), pp. 245-249. 